Relations industrielles

Industrial Relations

\title{
A Statement of Employer-Employee Relations
}

\section{Roger Vézina}

Volume 5, numéro 4, janvier 1950

URI : https://id.erudit.org/iderudit/1023318ar

DOI : https://doi.org/10.7202/1023318ar

Aller au sommaire du numéro

\section{Éditeur(s)}

Département des relations industrielles de l’Université Laval

\section{ISSN}

0034-379X (imprimé)

1703-8138 (numérique)

Découvrir la revue

Citer cet article

Vézina, R. (1950). A Statement of Employer-Employee Relations. Relations

industrielles / Industrial Relations, 5(4), 33-35. https://doi.org/10.7202/1023318ar

Tous droits réservés @ Département des relations industrielles de l’Université Laval, 1950
Ce document est protégé par la loi sur le droit d'auteur. L'utilisation des services d'Érudit (y compris la reproduction) est assujettie à sa politique d'utilisation que vous pouvez consulter en ligne.

https://apropos.erudit.org/fr/usagers/politique-dutilisation/ 


\title{
A STATEMENT OF EMPLOYER-EMPLOYEE RELATIONS
}

\author{
ROGER VÉzina
}

The Canadian Chamber of Commerce has just published the results of a survey ${ }^{1}$ conducted in some 1,300 Canadian enterprises having in their employ ten or more workers. The questionnaire, which the employers answered, was divided into two parts and covered the vast field of employer-employee relations on one hand, and the measures of social security, properly speaking, on the other. The results of the inquiry demonstrate that if employer-employee relations are still in their infancy, social security measures have made giant strides in the last few years. In the majority of the enterprises consulted group insurance and pension plans existed already, as well as hospitalization and sickness indemnities. The four tables which illustrate this article, kindly put at our disposal by "Canadian Business », official organ of the Canadian Cham-

(1) Survey Results Employer-Employee Relations 1949. - Issued by the Canadian Chamber of Commerce, 530, Board of Trade Building, Montreal. 75 cts per copy. ber of Commerce, are very revealing on this last claim.

\section{Employer-Employee \\ Relations}

The first part of the questionnaire, dealing with employer-employee relations, contained no less than eighteen questions designed to show the numerous ways of establishing and maintaining such relations and the degree of popularity in the enterprise of each of them. Compiled in a good sixty statistical tables, the answers received were separated into two general groups. The first illustrated the total of the responses given by the 1,309 enterprises, which themselves were divided into five numerical groups: from 10 to 99,100 to 249,250 to 499,500 to $999,1,000$ to 4,999 and 5,000 employees and more. The second illustrated the total of the responses given by only the manufacturing enterprises, 730 in all, which themselves were divided into five numerical groups of 10 to 99 employees, etc., etc. It goes without saying that it is abso- lutely impossible for us to analyse in the bounds of this brief article, statistical tables which embrace not less than a good fifty pages. We will content ourselves then with some findings capable of showing the degree of popularity of such and such a policy of employeremployee relations, such and such a measure of social security.

Thus, the answers given show that:

1. In 456 enterprises, of which 321 are manufacturies (out of a total of 1,309 ) one or more persons are occupied specially with the problem of employer-employee relations. Expressed in percentages the totals give us $35 \%$ of all the enterprises consuited and $44 \%$ of the enterprises only manufacturing;

2. To date, only 167 enterprises, or $13 \%$ of the total, have already consulted the opinion of their employees;

\section{Technigues des relations de travail}

The Report of the Fourth Annual Industrial Relations Convention of Laval University (1949), containing the conferences and the discussion, has just been printed. One can secure samples of this publication at the Département des relations industrielles, Faculté des sciences sociales, 2, rue de l'Université, Quebec City. Price : $\$ 1.50$ (franco).

Conferences: Conciliation et arbitrage (Me Louis-Philippe Pigeon); Organisation patronale (Louis Bilodeau); Organisation ouvrière (Jean Marchand); Négociation de la convention collective - aspect patronal (Hector Cimon); Négociation de la convention collective - aspect ouvrier (Rémi Duquette); Application de la convention collective et administration du personnel - aspect patronal (Lawrence A. Lyons); Application de la convention collective et délégués du personnel - aspect ouvrier (René Gosselin). 


\section{GROUP INSURANCE PLANS}

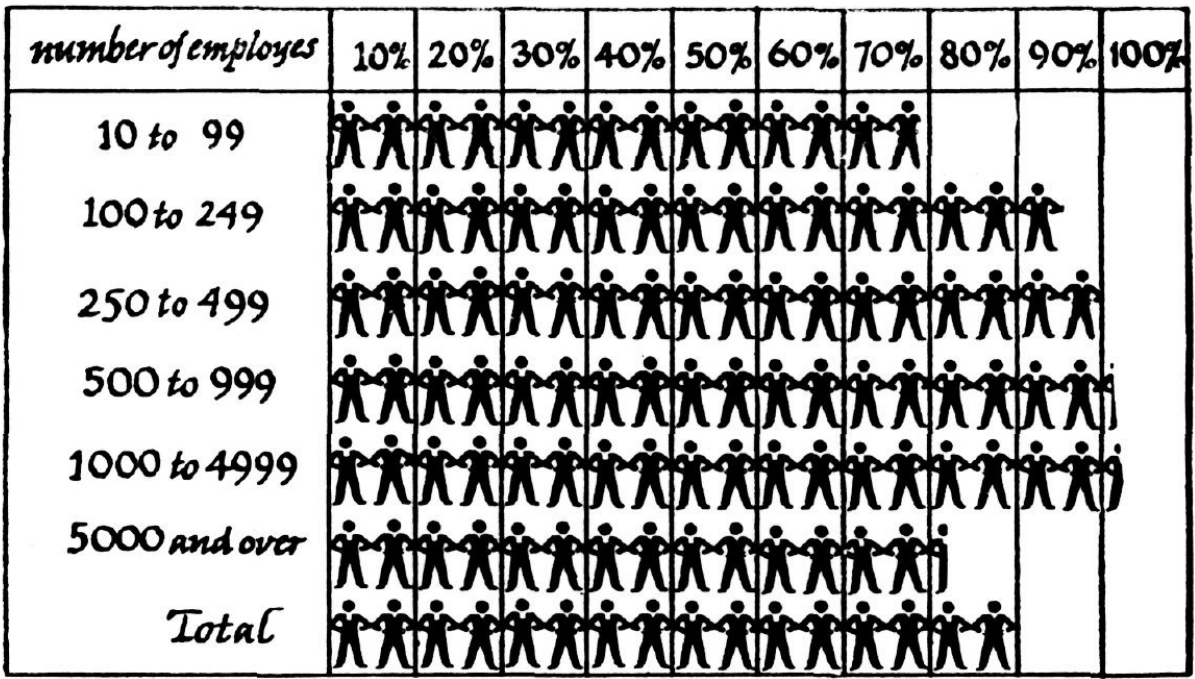

3. 355 , or $27 \%$ of the enterprises, publish a company manuel especially for their employees. The subjects treated in these handbooks bear either on the regulations or the policy or the aims or again on the history of the company or some similar subject;

4. 611 , or $47 \%$ of the total, have a policy of initiating their new employees through presentation to the administrative officers, a tour of the plant, explanations of its working, etc.;

5. Under the form of bulletins, letters, circulars, etc. printed or stencilled, monthly or weekly, etc., 355 enterprises, or $27 \%$, send publications to their employees;

6. 734 enterprises, or $56 \%$, call their employees together in general meetings or in small groups or in both ways at the same time;

7. 981 , or $75 \%$ of the total, organize meetings for the foremen and other leaders of the personnel;
8. 177 , or $13 \%$, have a training program for the directors of the enterprise;

9. 330 , or $25 \%$, train their foremen;

10. 421 , or $32 \%$, train their employees;

11. 450 , or $34 \%$, encourage visiting their plants, hold or participate in the exhibiting of their products. Excluding the enterprises that for one reason or another cannot follow such a plan, the percentage rises to $59 \%$;

12. Regularly or occasionally, by letters, bulletins or other- wise, 457 enterprises, or $35 \%$, communicate in some fashion with their employees at their home;

13. $86 \%$ of the enterprises periodically place bulletins at strategic points;

14. $13 \%$ of the enterprises circularize the annual report of the company among their employees and $4.5 \%$ have a special edition of this report for their employees;

15. 520 , or $40 \%$ have adopted some profit-sharing system under the form of bonus or otherwise;

16. 332 , or $25 \%$, have a system of checking the output of their workers;

17. 279 , or $21 \%$, stress the valuating and rewarding of effort;

18. 562 , or $43 \%$, have adopted a definite policy of promotion;

19. 306 , or $23 \%$, go in for public relations by means of the local newspapers.
EMPLOYEE PENSION PLANS

\begin{tabular}{|c|c|c|c|c|c|c|c|c|c|c|}
\hline nscomber of employes & $10 \%$ & $20 \%$ & $30 \%$ & $40 \%$ & $50 \%$ & $60 \%$ & $70 \%$ & $80 \%$ & $90 \%$ & $100 \%$ \\
\hline 10 to 99 & 2 & 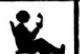 & 2 & 29 & & & & & & \\
\hline 100 to 249 & & 8 & 2 & 24 & 29 & & & & & \\
\hline 250 to 499 & & eq & & 2 & & $y$ & & & & \\
\hline 500 to 999 & & 2 & $\theta$ & 28 & 2 & 2 & 2 & & & \\
\hline 1000 to 4999 & & & 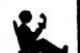 & & & 2 & & 22 & & \\
\hline 5000 and over & 22 & 2 & 2 & 29 & 28 & 2 & $\varphi$ & 2 & & \\
\hline Total & 29 & 29 & 2 & & 29 & & & & & \\
\hline
\end{tabular}


Social Security

1. 1,042 enterprises out of a total of 1,309 , that is $80 \%$, and 610 enterprises specifically manufacturing, out of a total of 730 , that is $83.5 \%$, have adopted some plan of group insurance. Of the grand total, 810 have decided in favour of a contributory plan, 147 in favour of a non-contributory plan and 62 abstain from clarifying the point;

2. 657 enterprises out of 1,309 , i.e. $50 \%$ of the total, and 365 enterprises specifically manufacturing out of 730 , i.e. again $50 \%$, have adopted a pension plan. Of the grand total, 533 are contributory and 101 non-contributory. About twenty refrained from going into detail;

3. Out of the 635 enterprises having no pension plan, 166 aid their retired employees in some manner, 346 do nothing, and 123 do not clarify the point;

4. 988 enterprises, or $75.5 \%$ of the total, insure that their
GROUP HOSPITALIZATION SCHEMES

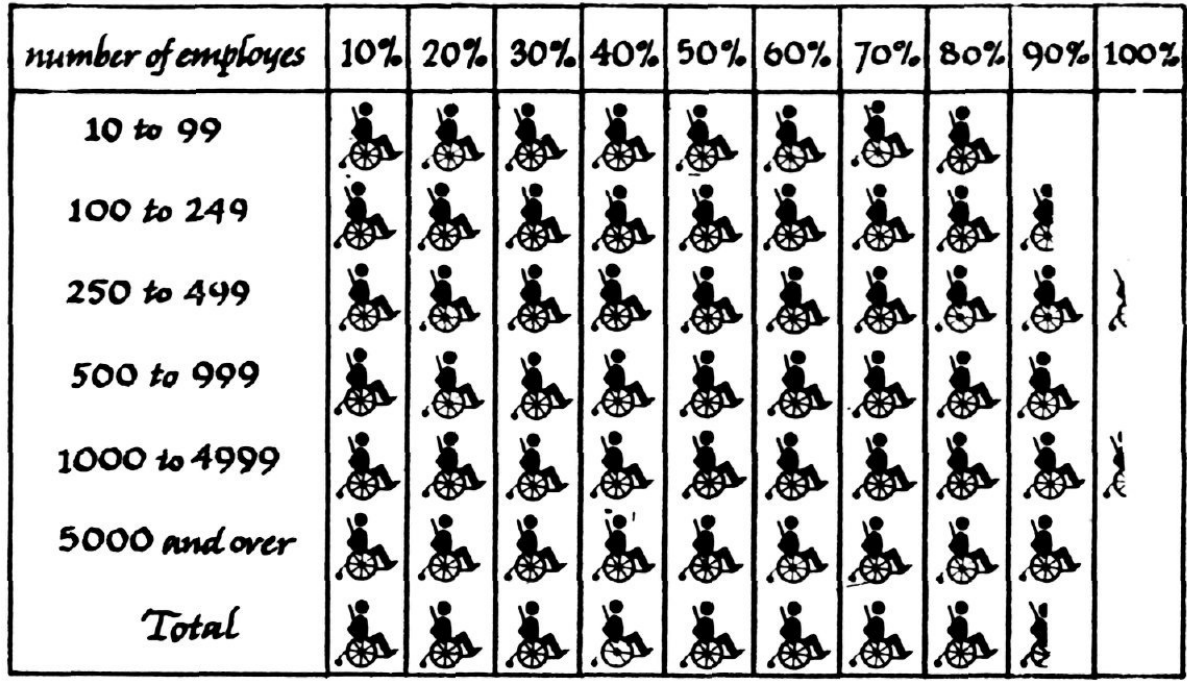

employees profit from sickness indemnities. In 426 enterprises the indemnities are established on a contributory basis, in 380 on a non-contributory basis. The remainder are indefinite;

5. 1,112 establishments, or $85.5 \%$ of the total, provide for the hospitalization of their employees. Of this total, 857 have a contributory hospitalization plan, 166 a non-contributory plan, and 99 fail to be definite;

6. 435 enterprises, or $33 \%$ of the total, have worked out

SICK BENEFITS FOR ABSENCES DUE TO ILLNESS

\begin{tabular}{|c|c|c|c|c|c|c|c|c|c|c|}
\hline number of employes & $10 \%$ & $20 \%$ & $30 \%$ & $40 \%$ & $50 \%$ & $60 \%$ & |70\% & $80 \%$ & $90 \%$ & $100 \%$ \\
\hline 10 to 99 & & & & & & & & & & \\
\hline 100 to 249 & & & & & & & & & & \\
\hline 250 to 499 & & & & & & & & & 8 & \\
\hline 500 to 999 & & & & & & & & & & \\
\hline 1000 to 4999 & & & & & & & & & & |s \\
\hline 5000 and over & & & & & & & & & & 8 \\
\hline Total & & & & & & & & 7 & & \\
\hline
\end{tabular}

a recreational program for their employees;

7. 372 , or $28.5 \%$ of the total have a medical service provided with a specialized personnel;

8. 390 , or $30 \%$ of the total, have a compulsory medical examination for their prospective employees;

9. 299 , or $22 \%$ of the enterprises consulted have a compulsory periodical medical examination;

10. 396 , or $30 \%$ of the total, operate restaurants for the personnel. In $34.5 \%$ the restaurants are operated at cost price, in $37 \%$ below cost price and in $16 \%$ above cost price. The $12 \%$ remaining gave no details;

11. Finally, to the question: «Are your labourers members of a union ? », the 730 manufacturies consulted responded as follows:« Yes », 416 enterprises, or a total of $56 \%$; « No », 274, or $38 \%$; «partly 》, 34 or $5 \%$; no details, 6 or $1 \%$. 